\title{
Co-occurrence of Dinophysis tripos and pectenotoxins in Argentinean shelf waters
}

\author{
Elena Fabro ${ }^{\mathrm{a}, \mathrm{b}}$, Gastón O. Almandoz ${ }^{\mathrm{a}, \mathrm{b}}$, Martha E. Ferrario ${ }^{\mathrm{a}, \mathrm{b}}$, Mónica S. Hoffmeyer ${ }^{\mathrm{b}, \mathrm{c}, \mathrm{d}}$, \\ Rosa E. Pettigrosso ${ }^{\mathrm{e}}$, Román Uibrig ${ }^{\mathrm{d}}$, Bernd Krock ${ }^{\mathrm{f}, *}$ \\ a División Ficología, Facultad de Ciencias Naturales y Museo, Universidad Nacional de La Plata, Paseo del Bosque s/n, B1900FWA La Plata, Argentina \\ ${ }^{\mathrm{b}}$ Consejo Nacional de Investigaciones Científicas y Técnicas (CONICET), Av. Rivadavia 1917, 1033 Buenos Aires, Argentina \\ ${ }^{c}$ Facultad Regional de Bahía Blanca, Universidad Tecnológica Nacional, 11 de Abril 461, B8000LMI Bahía Blanca, Argentina \\ ${ }^{\mathrm{d}}$ Instituto Argentino de Oceanografía (CCTBB CONICET), Camino La Carrindanga km 7.5, B8000FWB Bahía Blanca, Argentina \\ e Departamento de Biología, Bioquímica y Farmacia, Universidad Nacional del Sur, San Juan 670, 8000 Bahía Blanca, Argentina \\ ${ }^{\mathrm{f}}$ Alfred Wegener Institut-Helmholtz Zentrum für Polar- und Meeresforschung, Chemische Ökologie, Am Handelshafen 12,27570 Bremerhaven, Germany
}

A R T I C L E I N F O

\section{Article history:}

Received 21 August 2014

Received in revised form 18 December 2014

Accepted 18 December 2014

Available online

\section{Keywords:}

Lipophilic toxins

LC-MS/MS

Dinophysis tripos

Morphological variability

Zooplankton bioaccumulation

South Atlantic

\begin{abstract}
A B S T R A C T
The species Dinophysis tripos is a widely distributed marine dinoflagellate associated with diarrheic shellfish poisoning (DSP) events, which has been recently identified as a pectenotoxin (PTX) producer. In two sampling expeditions carried out during austral autumns 2012 and 2013 along the Argentine Sea $\left(\approx 38-56^{\circ} \mathrm{S}\right)$, lipophilic phycotoxins were measured by tandem mass spectrometry coupled to liquid chromatography (LC-MS/MS) in size-fractionated plankton samples together with microscopic analyses of potentially toxic phytoplankton. PTX-2, PTX-11 and PTX-2sa were recurrently detected in the 50$200 \mu \mathrm{m}$ fractions, in association to $D$. tripos. PTX-2 was also widely distributed among the 20-50 $\mu \mathrm{m}$ fractions, mostly related to Dinophysis acuminata. Okadaic acid or its analogs were not detected in any sample. This is the first report of $D$. tripos related to PTX in the Argentine Sea and the first record of PTX11 and PTX-2sa for this area. The morphological variability of $D$. tripos, including the presence of intermediate, small and dimorphic cells, is described. Also, the micro- and mesoplanktonic potential grazers of Dinophysis spp. were explored.
\end{abstract}

(c) 2015 Elsevier B.V. All rights reserved.

\section{Introduction}

The genus Dinophysis Ehrenberg is represented by more than 120 species of marine dinoflagellates, including phototrophic and mixotrophic species (Hastrup-Jensen and Daugbjerg, 2009; Gómez et al., 2011). Of these, 10 toxic species are known as the main source of okadaic acid and its analogs, causative of diarrheic shellfish poisoning (DSP) in humans (Reguera et al., 2014). A few hundred cells per liter are enough to generate intoxications in humans by consuming contaminated shellfish (Yasumoto et al., 1980). Up to date, dinoflagellate species of the genus Dinophysis have been recently recognized as the only known source of pectenotoxins (PTX), a large family of lipophilic toxins originally associated with the DSP toxin complex (Reguera et al., 2014). Toxicological studies indicate that PTX are not diarrheagenic after oral administration to laboratory rodents, but PTX- 1 is highly

\footnotetext{
* Corresponding author. Tel.: +49 4714831 2055; fax: +49 47148311425.

E-mail address: bernd.krock@awi.de (B. Krock).
}

hepatotoxic and the other analogs are assumed to have similar effects (Terao et al., 1986). Reported lethal doses $\left(\mathrm{LD}_{50}\right)$ by intraperitoneal injection (i.p.) in mice for PTXs are detailed in Domínguez et al. (2010). Cytotoxicity in different human cancer lines and induction of apoptosis in rat and salmon hepatocytes has been also attributed to some PTX (Domínguez et al., 2010). The existence of different published results reported by different groups has raised a controversy about the diarrheic activity and oral toxicity of PTX.

Unlike DSP toxins as okadaic acid, which are known to accumulate through the food web and concentrate in somatic tissues of zooplanktonic organisms (Teegarden \& Cembella, 1996; Suzuki et al., 1998; Maneiro et al., 2000; Tester et al., 2000), as far as we know there is no evidence of PTX bioaccumulation in zooplankton, although copepod grazing on Dinophysis spp. (Maneiro et al., 2002; Kozlowsky-Suzuki et al., 2006) is well known. Pectenotoxin-2 was detected in copepods incubated with Dinophysis spp. (Setälä et al., 2009), but the absence of this toxin in individual copepods isolated from field zooplankton samples led the authors to conclude that a toxin transfer through the food web 
could not be proven (Setälä et al., 2011). However, PTX metabolized by enzymatic hydrolysis have been found in mussels (Miles et al., 2004b; Wilkins et al., 2006).

Pectenotoxins are cyclic polyether lactones that differ structurally from each other by different degrees of oxidation, different arrangements of the spiroketal ring system, and opening of the large lactone ring (Quilliam, 2003). These toxins are globally distributed and recurrently found at the southeast Pacific coast of Chile (Blanco et al., 2007; Krock et al., 2009; Trefault et al., 2011). In Argentinean waters, the presence of PTX-2 was recently detected in the Buenos Aires province coast (Montoya et al., 2013), and in the San Jorge Gulf (B. Krock, unpubl. data).

In the IOC-UNESCO reference list of toxic microalgae (Zingone \& Larsen, 2014) Dinophysis tripos Gourret is one of the 10 Dinophysis species included. Detection of DTX-1 in picked cells from Kesennuma Bay (Japan) using liquid chromatography with fluorescence detection (LC-FLD) was the first record of toxin production by this species (Lee et al., 1989). However, these toxins were not detected later in $D$. tripos isolates from Japan analyzed by liquid chromatography-tandem mass spectrometry (LC-MS/MS) (Suzuki et al., 2009). More recently, the presence of PTX-2 in D. tripos was detected for the first time in field samples and cultures from Galician Rías also using LC-MS analyses (Rodríguez et al., 2012). In accordance, the production of PTX-2 and to a much lesser extent of DTX-1 was recently proven in Japanese cultures of $D$. tripos using LC-MS/MS (Nagai et al., 2013).

The species Dinophysis tripos is widely distributed in subtropical and tropical waters, but can also be observed in colder regions such as the northern Norwegian Sea and subantarctic waters of the South Atlantic (Johnsen \& Lømsland, 2010). In the Argentine Sea, it is known to occur between $\approx 36$ and $55^{\circ} \mathrm{S}$ (Balech, 2002), and it has been frequently observed along northern coastal waters of Buenos Aires Province $\left(36-37^{\circ} \mathrm{S}\right)$, reaching densities up to $3 \times 10^{2}$ cell $\mathrm{L}^{-1}$ (Sar et al., 2010). The distinctive cell shape and size, including the presence of two posterior hypothecal projections, allow the differentiation of $D$. tripos from other related species (Balech, 1988; Larsen \& Moestrup, 1992). However, the presence of atypical intermediate and small cell forms of $D$. tripos, originally described as Dinophysis diegensis var. curvata Kofoid, as well as dimorphic forms result of "depauperating" cell division can also be observed (Reguera \& González-Gil, 2001; Rodríguez et al., 2012).

With the purpose of studying potentially toxic microalgae and their toxins in Argentinean shelf waters, two expeditions took place covering an extended area $\left(\approx 38-56^{\circ} \mathrm{S}\right)$. In addition, the occurrence of possible predators of Dinophysis tripos was also analyzed in order to study possible toxin transfer through the food web. In this work, we describe the recurrent finding of pectenotoxins associated with the dinoflagellate $D$. tripos, providing the first report linking this species with toxins in the Argentine Sea. A description of different morphological forms of $D$. tripos observed in the area is also presented.

\section{Materials and methods}

\subsection{Sampling}

The continental shelf waters of the Argentine Sea were sampled during two expeditions. The first one was carried out onboard the $R / V$ "Puerto Deseado" from March 30th to April 14th, 2012. A total of 46 stations were sampled between $\approx 38^{\circ}$ and $55^{\circ} \mathrm{S}$ (Fig. 1 ). The second was performed on the $R / V$ "Bernardo Houssay" from March 11th to March 22nd, 2013 with 24 sampling points located between $\approx 39^{\circ}$ and $43^{\circ} \mathrm{S}$. It consisted of two legs, K1 (eight stations) and $\mathrm{K} 2$ (16 stations).

Plankton samples were collected by vertical net tows through the upper $20 \mathrm{~m}$ of the water column with a $20 \mu \mathrm{m}$-mesh Nitex net

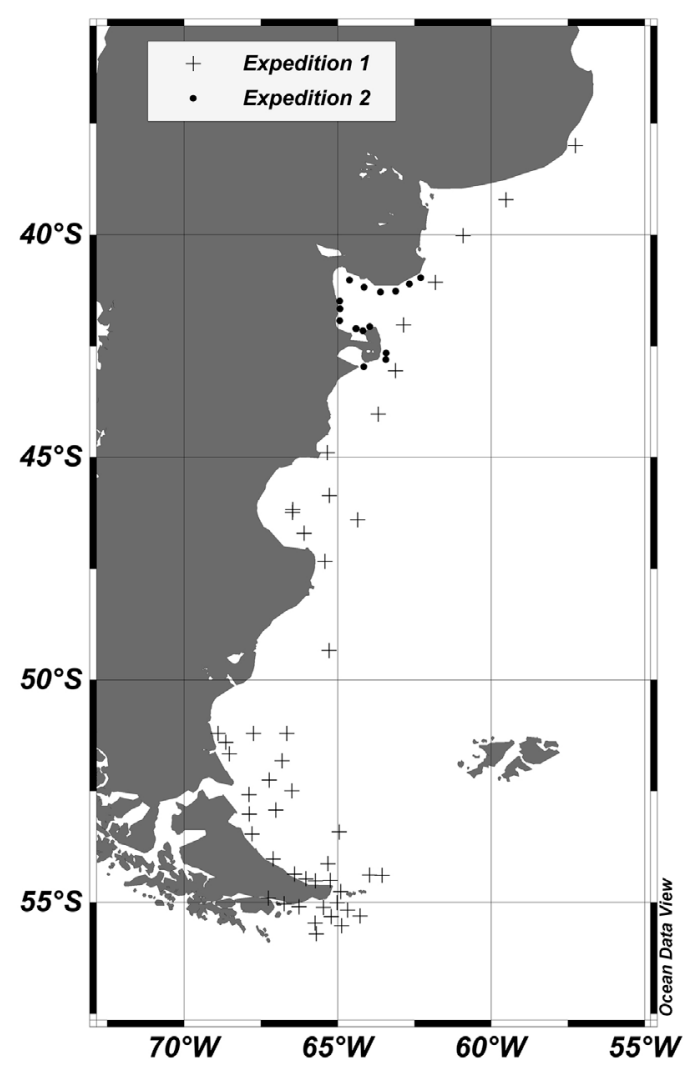

Fig. 1. Map of the study area showing the location of sampling points.

for both plankton and phycotoxins analysis. Each net haul was taken up to $1 \mathrm{~L}$ with $0.2 \mu \mathrm{m}$ filtered sea water, of which $20 \mathrm{~mL}$ and $100 \mathrm{~mL}$ were fixed with Lugol's solution during expedition 1 and 2 respectively, for species determination and enumeration. The rest was sequentially filtered through Nitex mesh of 200, 50 and $20 \mu \mathrm{m}$ by gravity filtration and split into aliquots for extraction of toxins.

\subsection{Phytoplankton analysis}

Cell abundance of Dinophysis spp. in net tow concentrates was determined by counting $1 \mathrm{~mL}$ of Lugol fixed samples using Sedgewick-Rafter chambers (LeGresley \& McDermott, 2010) with an inverted microscope (Leica DMIL LED). Further morphological examination was made with a phase contrast/differential interference contrast Leica DM2500 microscope equipped with a DFC420C camera, and a scanning electron microscope (FEI Quanta FEG 200, Eindhoven, Netherlands).

\subsection{Zooplankton analysis}

Samples (20 $\mu$ m-mesh net) from the leg K2 of expedition 2 ( $n=16$ ) were also analyzed for microzooplankton $(20-200 \mu \mathrm{m}$ and $>200 \mu \mathrm{m}$ in size) analysis. The latter were identified to the low taxonomic possible level and enumerated following the Utermöhl method (Utermöhl, 1931) using appropriate literature (Boltovskoy, 1981; Balech, 1988; Montagnes et al., 1988; Montagnes \& Lynn, 1991; Montagnes \& Taylor, 1994; Agatha \& Riedel-Lorje, 1997; Alder, 1999; Petz, 1999; Kogan, 2005). Each sample was well homogenized and $10 \mathrm{~mL}$ allowed settling for $24 \mathrm{~h}$. After that, all organisms in the base chamber were identified and counted under a Nikon Eclipse TS100 inverted microscope. Some possible predators of Dinophysis spp. present in samples (including those of $>200 \mu \mathrm{m}$ of size) were examined in more detail under the 
mentioned inverted microscope, a Nikon SMZ 1500 stereomicroscope and a Nikon Eclipse 80i microscope sometimes using methylene blue stain to get better contrast. Images from them were obtained using a Nikon DXM 1200F digital camera which were later processed with Image Pro plus software (Media Cybernetics).

\subsection{Toxin analysis}

Cell pellets from the plankton net tow size fractions were collected by centrifugation $\left(3220 \times \mathrm{g}, 15 \mathrm{~min}\right.$ at $4{ }^{\circ} \mathrm{C}$ ), suspended in $500 \mu \mathrm{L}$ methanol, and subsequently homogenized with $0.9 \mathrm{~g}$ of lysing matrix $\mathrm{D}$ by reciprocal shaking at maximum speed $\left(6.5 \mathrm{~m} \mathrm{~s}^{-1}\right)$ for $45 \mathrm{~s}$ in a Bio101 FastPrep instrument (Thermo Savant, Illkirch, France). After homogenization, samples were centrifuged at $16,100 \times g$ at $4{ }^{\circ} \mathrm{C}$ for $15 \mathrm{~min}$. The supernatant was transferred to a spin-filter $(0.45 \mu \mathrm{m}$ pore-size, Millipore Ultrafree, Eschborn, Germany) and centrifuged for $30 \mathrm{~s}$ at $800 \times \mathrm{g}$, followed by transfer to autosampler vials. Analysis of multiple lipophilic toxins was performed by liquid chromatography coupled to tandem mass spectrometry (LC-MS/MS), as described in Krock et al. (2008).

\section{Results}

\subsection{Plankton and phycotoxin analysis}

\subsubsection{Expedition 1}

The most frequent Dinophysis spp. observed along expedition 1 was Dinophysis acuminata $(\approx 37-45 \mu \mathrm{m})$, occurring in $82 \%$ of the stations in abundances from $1 \times 10^{3}$ to $168 \times 10^{3}$ cells NT ${ }^{-1}$. However, the maximum Dinophysis abundance $\left(20.7 \times 10^{4}\right.$ cells $\left.\mathrm{NT}^{-1}\right)$ was reached by Dinophysis tripos $(\approx 70$ $90 \mu \mathrm{m})$ at station $\mathrm{I} 50\left(\approx 40^{\circ} \mathrm{S}\right)$, while no other Dinophysis species was observed at this sampling point. In fact, the presence of $D$. tripos during the expedition 1 was almost confined to station I50, since it appeared in only two more stations in very low abundances $\left(1-2 \times 10^{3}\right.$ cells $\left.\mathrm{NT}^{-1}\right)$ (Fig. $2 \mathrm{~A}$ ).

Analysis of phycotoxins revealed a very high abundance of PTX2sa (2396 $\mathrm{ng} \mathrm{NT}^{-1}$ ) in the $50-200 \mu \mathrm{m}$ fraction size at station I50
(Fig. 2B). Pectenotoxin-2 seco acid appeared in this size fraction in only five more samples but in lower concentrations (from 104 to $266 \mathrm{ng} \mathrm{NT}^{-1}$ ). Also low concentrations of PTX-2 (from 106 to $578 \mathrm{ng} \mathrm{NT}^{-1}$ ) were detected in four samples in this fraction size (Fig. 2B). In contrast, in the $20-50 \mu \mathrm{m}$ size fractions, the most distributed toxin was PTX-2, occurring in $61 \%$ of the stations (data not shown). In this fraction, also PTX-2sa was detected in 15 samples in trace concentrations $\left(<35 \mathrm{ng} \mathrm{NT}^{-1}\right)$ and in two samples in low values ( 56 and $78 \mathrm{ng} \mathrm{NT}^{-1}$ ). Pectenotoxin-2 seco acid was the only toxin present in the $>200 \mu \mathrm{m}$ size fraction, with a maximum value at station I50 $\left(107 \mathrm{ng} \mathrm{NT}^{-1}\right)$. No okadaic acid or its analogs were detected in any size fraction.

\subsubsection{Expedition 2}

The most common Dinophysis species observed along expedition 2 was Dinophysis tripos $(\approx 79-100 \mu \mathrm{m})$, being present in 12 stations located between $\approx 41^{\circ}$ and $43^{\circ} \mathrm{S}$ (leg K2). It represented an average of $83 \%$ of the total abundance of the genus, with densities ranging between $11 \times 10^{3}$ cells NT ${ }^{-1}$ and $3800 \times 10^{3}$ cells $\mathrm{NT}^{-1}$ (Fig. 3A). The species Dinophysis acuminata ( $\approx 25-45 \mu \mathrm{m})$ was also present in nine of total samples, but in lower abundances, from 1 to $22 \times 10^{3}$ cells $\mathrm{NT}^{-1}$.

Toxin analyses showed the presence of three PTX in the 50$200 \mu \mathrm{m}$ size fractions: PTX-2, PTX-11 and PTX-2sa. The latter was the most abundant toxin, being present in $50 \%$ of the samples and confined to the same 12 stations where Dinophysis tripos was found, whereas PTX-2 and PTX-11 were detected in $46 \%$ and $21 \%$ of stations, respectively (Fig. 3B). The maximum levels of PTX-2sa, PTX-2 and PTX-11 were 3002,1317 and $512.5 \mathrm{ng} \mathrm{NT}^{-1}$ respectively (Table 1 ). In the $20-50 \mu \mathrm{m}$ size fractions only trace concentrations of the three toxins were found; PTX-2 appeared at 12 stations, PTX2 sa at 10 stations, and PTX-11 at only 1 station (data not shown). In the $>200 \mu \mathrm{m}$ size fractions, PTX-2 and PTX-2sa were detected also in trace concentrations in two and nine samples respectively, but PTX-2sa also appeared in one sample showing a higher value (630 ng NT ${ }^{-1}$ ).

High and significant $(p<0.05)$ Spearman correlations coefficients were found between Dinophysis tripos abundance and PTX-2 $(r=0.91)$, and PTX-2sa $(r=0.96)$ concentrations. No okadaic acid or its analogs were detected in any size fraction.
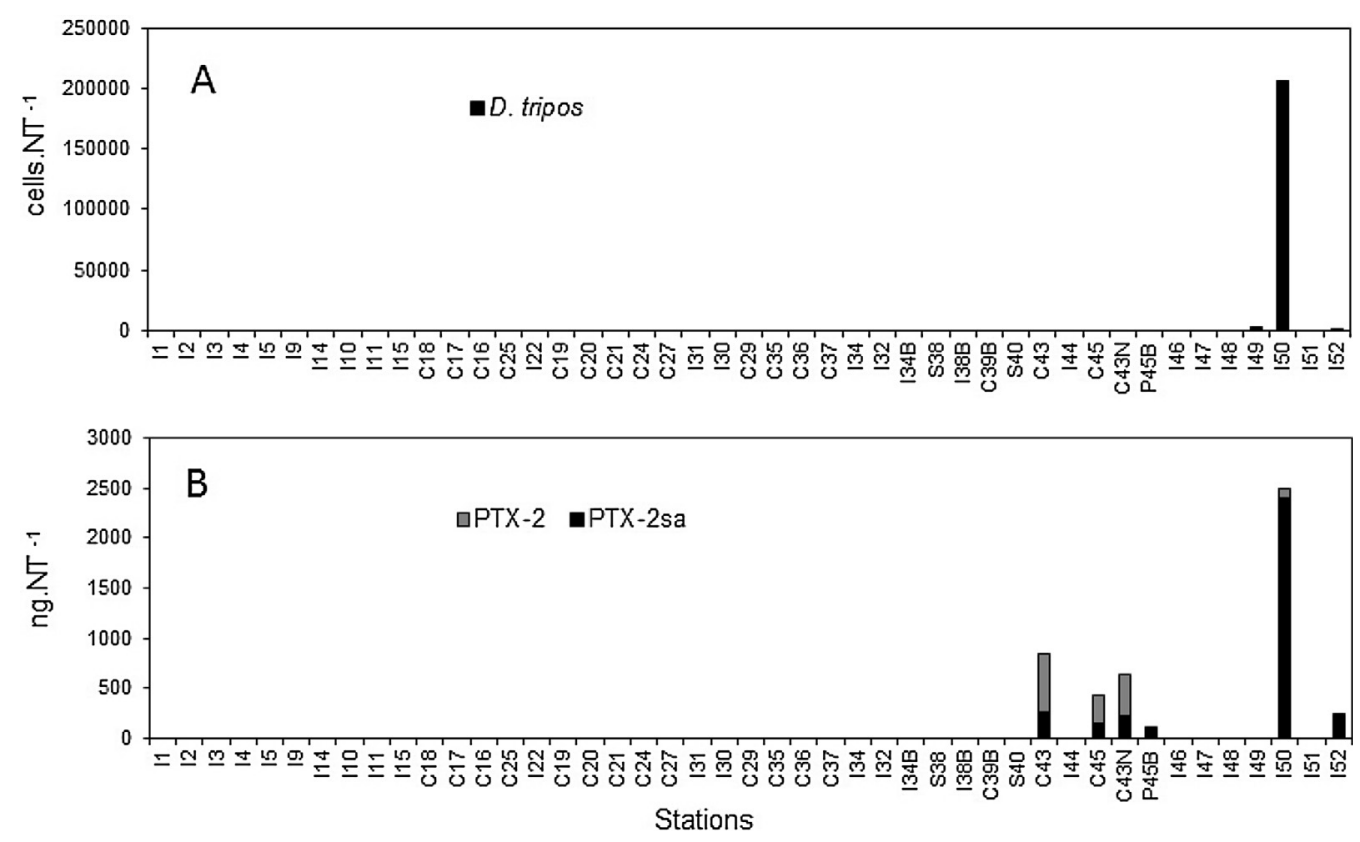

Fig. 2. Distribution of PTXs concentration in the 50-200 $\mu \mathrm{m}$ fraction size and $D$. tripos abundances, during the first expedition in the Argentine Sea. 

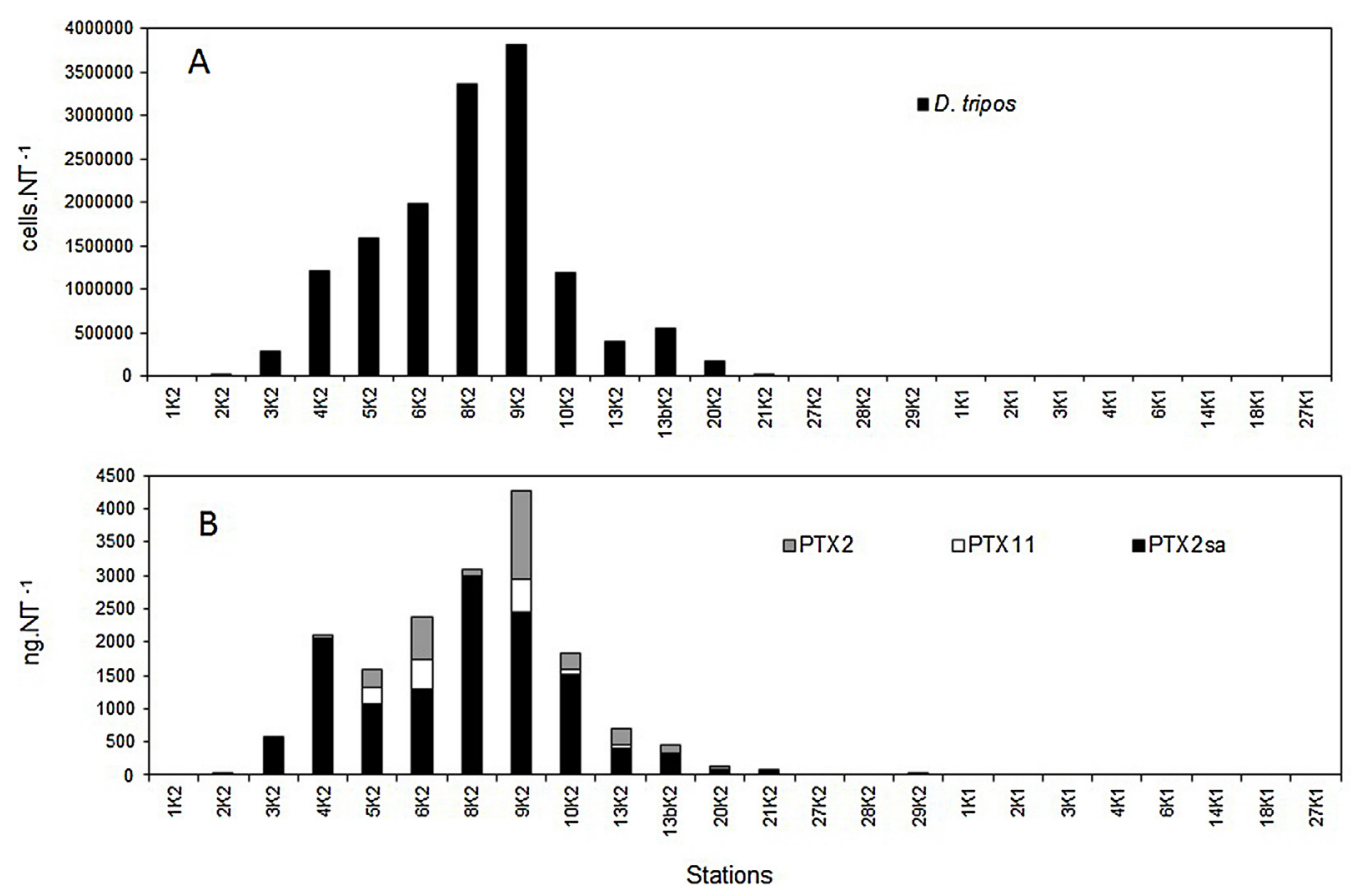

Fig. 3. Distribution of PTXs concentration in the 50-200 $\mu \mathrm{m}$ fraction size and D. tripos abundances, during the second expedition in the Argentine Sea.

Table 1

Co-occurrence of pectenotoxins (PTXs) and D. tripos, and estimated toxin cell quotas in the 50-200 $\mu \mathrm{m}$ size fractions of net samples collected during the second expedition in the Argentine Sea.

\begin{tabular}{|c|c|c|c|c|c|c|c|c|c|}
\hline Sample & $\begin{array}{l}\text { PTX2sa } \\
\left(\mathrm{ng} \mathrm{NT}^{-1}\right)\end{array}$ & $\begin{array}{l}\text { PTX2 } \\
\left(\operatorname{ng~NT}^{-1}\right)\end{array}$ & $\begin{array}{l}\text { PTX11 } \\
\left(\mathrm{ng} \mathrm{NT}^{-1}\right)\end{array}$ & $\begin{array}{l}\text { Total } \\
\left(\mathrm{ng} \mathrm{NT}^{-1}\right)\end{array}$ & $\begin{array}{l}\text { Dinophysis tripos } \\
\text { (cells } 10^{3} \mathrm{NT}^{-1} \text { ) }\end{array}$ & $\begin{array}{l}\text { PTX2sa } \\
\left(\text { pg cell }^{-1}\right)\end{array}$ & $\begin{array}{l}\text { PTX2 } \\
\left(\text { pg cell }^{-1}\right)\end{array}$ & $\begin{array}{l}\text { PTX11 } \\
\left(\text { pg cell }^{-1}\right)\end{array}$ & $\begin{array}{l}\text { Total } \\
\left(\operatorname{pg~cell}^{-1}\right)\end{array}$ \\
\hline $2 \mathrm{~K} 2$ & 27.0 & 0.0 & 0.0 & 27.0 & 13 & 2.07 & 0.00 & 0.00 & 2.07 \\
\hline $3 \mathrm{~K} 2$ & 560.7 & 6.9 & 0.0 & 567.6 & 273 & 2.05 & 0.03 & 0.00 & 2.08 \\
\hline $4 \mathrm{~K} 2$ & 2057.4 & 55.9 & 0.0 & 2113.3 & 1180 & 1.74 & 0.05 & 0.00 & 1.79 \\
\hline $5 \mathrm{~K} 2$ & 1069.7 & 280.6 & 245.1 & 1595.4 & 1570 & 0.68 & 0.18 & 0.16 & 1.02 \\
\hline $6 \mathrm{~K} 2$ & 1282.4 & 639.3 & 459.2 & 2380.9 & 1970 & 0.65 & 0.32 & 0.23 & 1.21 \\
\hline $8 \mathrm{~K} 2$ & 3001.9 & 100.4 & 0.0 & 3102.3 & 3350 & 0.90 & 0.03 & 0.00 & 0.93 \\
\hline $9 K 2$ & 2441.2 & 1316.9 & 512.5 & 4270.7 & 3800 & 0.64 & 0.35 & 0.13 & 1.12 \\
\hline $10 \mathrm{~K} 2$ & 1505.3 & 229.5 & 90.5 & 1825.3 & 1133 & 1.33 & 0.19 & 0.08 & 1.61 \\
\hline $13 \mathrm{~K} 2$ & 414.5 & 238.8 & 48.1 & 701.3 & 405 & 1.02 & 0.06 & 0.12 & 1.73 \\
\hline 13bK2 & 323.1 & 123.7 & 0.0 & 446.8 & 295 & 1.10 & 0.04 & 0.00 & 1.51 \\
\hline $20 \mathrm{~K} 2$ & 81.5 & 42.5 & 0.0 & 124.0 & 170 & 0.48 & 0.03 & 0.00 & 0.73 \\
\hline $21 \mathrm{~K} 2$ & 68.1 & 3.4 & 0.0 & 71.6 & 11 & 6.20 & 0.03 & 0.00 & 6.51 \\
\hline
\end{tabular}

Table 2

Abundances of potential predators of $D$. tripos present in the $20-200 \mu \mathrm{m}$ size fractions during the leg $\mathrm{K} 2$ of expedition 2 in the Argentine Sea.

\begin{tabular}{|c|c|c|c|c|c|c|c|c|c|c|c|c|c|c|c|c|}
\hline Station/cells NT ${ }^{-1}$ & $1 \mathrm{~K} 2$ & $2 \mathrm{~K} 2$ & $3 \mathrm{~K} 2$ & $4 \mathrm{~K} 2$ & $5 \mathrm{~K} 2$ & $6 \mathrm{~K} 2$ & $8 \mathrm{~K} 2$ & $9 \mathrm{~K} 2$ & $10 \mathrm{~K} 2$ & $13 \mathrm{~K} 2$ & $13 \mathrm{bK} 2$ & $20 \mathrm{~K} 2$ & $21 \mathrm{~K} 2$ & $27 \mathrm{~K} 2$ & $28 \mathrm{~K} 2$ & $29 \mathrm{~K} 2$ \\
\hline Gyrodinium spp. & 0 & 0 & 0 & 0 & 0 & 0 & 0 & 0 & 6195 & 0 & 3640 & 0 & 0 & 0 & 0 & 0 \\
\hline Tiarina fusus & 0 & 0 & 7735 & 13,350 & 5005 & 30,030 & 3540 & 0 & 1035 & 27,880 & 28,220 & 620 & 0 & 0 & 670 & 1098 \\
\hline Strombidinopsis acuminata & 0 & 0 & 0 & 1335 & 0 & 0 & 0 & 0 & 0 & 410 & 415 & 0 & 0 & 0 & 0 & 122 \\
\hline Strombidinopsis elongata & 0 & 0 & 0 & 0 & 0 & 0 & 0 & 0 & 0 & 0 & 0 & 0 & 0 & 0 & 0 & 61 \\
\hline Cyclotrichium gigas & 0 & 276 & 910 & 1335 & 0 & 1365 & 0 & 0 & 0 & 1230 & 1245 & 0 & 940 & 0 & 0 & 61 \\
\hline Codonellopsis obesa & 0 & 4920 & 840 & 0 & 0 & 0 & 0 & 0 & 0 & 0 & 0 & 0 & 0 & 0 & 1530 & 20,235 \\
\hline Favella taraikaensis & 0 & 0 & 0 & 0 & 0 & 0 & 0 & 0 & 0 & 0 & 0 & 0 & 0 & 0 & 0 & 570 \\
\hline Favella ehrenbergi & 0 & 168,100 & 8400 & 2765 & 21,060 & 810 & 0 & 0 & 9292 & 5040 & 12,775 & 4095 & 840 & 1890 & 0 & 11,970 \\
\hline
\end{tabular}

Zooplankton analyses revealed the presence of heterotrophic dinoflagellates, tintinnids, aloricate ciliates, different marine invertebrate larvae, cladocerans as well as nauplius larvae and copepodites of cyclopoid, calanoid and harpacticoid copepods. Taking into account their size, small and medium dinoflagellates, ciliates, some eggs and first nauplii of copepods belonged to microzooplankton $(<200 \mu \mathrm{m}$ size fraction), while the large heterotrophic dinoflagellate Noctiluca scintillans, copepod nauplii, copepodites and some adults, cladocerans and invertebrate larvae belonged to mesozooplankton ( $>200$ fraction). According to body measures, the potential predators of Dinophysis spp. (e.g., mainly Dinophysis tripos which was the dominant species of this genus in samples) in the $20-200 \mu \mathrm{m}$ size fraction and their abundances, are presented in Table 2. They belong to dinoflagellates, aloricate ciliates, and tintinnids, all microzooplanktonic groups. None of these taxa showed a distribution pattern related to that of PTX in 
Table 3

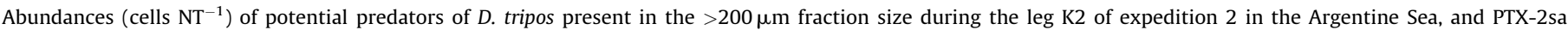
concentration (ng NT ${ }^{-1}$ ) in the same fraction.

\begin{tabular}{|c|c|c|c|c|c|c|c|c|c|c|c|c|c|c|c|c|}
\hline Sample & $1 \mathrm{~K} 2$ & $2 \mathrm{~K} 2$ & $3 \mathrm{~K} 2$ & $4 \mathrm{~K} 2$ & $5 \mathrm{~K} 2$ & $6 K 2$ & $8 \mathrm{~K} 2$ & $9 \mathrm{~K} 2$ & $10 \mathrm{~K} 2$ & $13 \mathrm{~K} 2$ & 13bK2 & $20 \mathrm{~K} 2$ & $21 \mathrm{~K} 2$ & $27 \mathrm{~K} 2$ & $28 \mathrm{~K} 2$ & $29 \mathrm{~K} 2$ \\
\hline PTX2sa (ng NT $\left.{ }^{-1}\right)$ & 0 & 0 & 18 & 7 & 4 & 8 & 630 & 50 & 17 & 23 & 4 & 47 & 0 & 0 & 0 & 0 \\
\hline $\begin{array}{l}\text { Noctiluca scintillans } \\
\quad\left(\text { cells } \mathrm{NT}^{-1}\right)\end{array}$ & 0 & 0 & 0 & 0 & 60,750 & 22,680 & 51450 & 2975 & 15,488 & 0 & 1820 & 1365 & 0 & 68,040 & 8670 & 0 \\
\hline $\begin{array}{l}\text { Copepodites Cyclopoida } \\
\quad\left(\text { cells NT }{ }^{-1} \text { ) }\right.\end{array}$ & 5000 & 11,480 & 3360 & 3950 & 15,390 & 17,010 & 6370 & 5100 & 8850 & 0 & 2555 & 780 & 0 & 1800 & 2550 & 7980 \\
\hline $\begin{array}{l}\text { Copepodites Calanoida } \\
\quad\left(\text { cells } \mathrm{NT}^{-1} \text { ) }\right.\end{array}$ & 13,000 & 27,880 & 15,120 & 15,010 & 33,210 & 38,070 & 14,210 & 17,000 & 24,485 & 15,120 & 25,550 & 7540 & 2520 & 18,720 & 7650 & 19,380 \\
\hline $\begin{array}{l}\text { Copepodites Harpacticoida } \\
\text { (cells } \mathrm{NT}^{-1} \text { ) }\end{array}$ & 0 & 4100 & 10,080 & 0 & 0 & 0 & 0 & 0 & 0 & 0 & 0 & 0 & 2520 & 0 & 510 & 0 \\
\hline
\end{tabular}

Table 4

Length $(L)$ and dorso-ventral depth $(E)$ of the hypothecal plates of normal, intermediate and small cell forms of $D$. tripos observed in the Argentine Sea.

\begin{tabular}{lccc}
\hline & Normal cells & Intermediate cells & Small cells \\
\hline$L$ range $(\mu \mathrm{m})$ & $79-100$ & $72-87$ & $59-70$ \\
$E$ range $(\mu \mathrm{m})$ & $42-50$ & $28-40$ & $25-32$ \\
$L$ average $(\mu \mathrm{m})$ & 94 & 79 & 65 \\
$E$ average $(\mu \mathrm{m})$ & 45 & 34 & 28 \\
\hline
\end{tabular}

the $50-200 \mu \mathrm{m}$ size fraction. Copepod fecal pellets were also frequently observed in this size fraction of samples but were not quantified. In the $>200$ size fraction Dinophysis spp. grazers as $N$. scintillans and other potential ones as different development stages of copepods appeared at all stations (Table 3).

\subsection{Dinophysis tripos morphology}

Dinophysis tripos normal cells are easily distinguished from other species by their typical cell shape, which includes two big posterior prolongations, one dorsal and the other ventral. Also the cell size is characteristic, ranging between 94 and $125 \mu \mathrm{m}$. Cingular lists are well developed and the left sulcal list is bigger than the right one (Balech, 1988).

Besides the normal shape of Dinophysis tripos another two different forms, intermediate and small cells according to Rodríguez et al. (2012), were commonly observed along the second expedition. These two morphotypes differ from the typical form in terms of length and dorso-ventral depth of the larger hypothecal plates (Table 4); development of dorsal horn, absent in small cells and reduced in intermediate cells (Fig. 4); and areolation, marked in normal cells but absent in small cell forms (Fig. 5).
Intermediate and small forms were present in 9 of 12 samples in which Dinophysis tripos was recorded. However, they represented only $0.18-2.54 \%$ (average of $0.86 \%$ ) of the total abundances of $D$. tripos. On the other hand, in the three samples in which only normal cells were found, the abundance of $D$. tripos was considerably low (maximum of $170 \times 10^{3}$ cells $\mathrm{NT}^{-1}$ ).

Recently divided vegetative cells, lacking the anterior or the posterior left sulcal list, were observed in all samples that contain Dinophysis tripos normal cells (Fig. 6A). In addition, dimorphic cells, result of depaupering division (Reguera \& González-Gil, 2001), were found. They presented different hypothecal plates in the same individual, one of them with normal appearance and the other one with intermediate or small cell characteristics (Fig. 6B and $\mathrm{C}$ ).

\section{Discussion}

The dinoflagellate genus Dinophysis is considered as the only source of PTX in marine waters (Reguera et al., 2014). Several PTX analogs have been found in culture conditions, field water samples and shellfish (Domínguez et al., 2010). The species Dinophysis fortii was the first one identified as a PTX producer (Lee et al., 1989; Draisci et al., 1996), but PTX have been later found in Dinophysis acuta (Suzuki et al., 2003), Dinophysis norvegica (Miles et al., 2004a; Suzuki et al., 2009), Dinophysis acuminata (MacKenzie et al., 2005), Dinophysis caudata (Fernández et al., 2006) and Dinophysis tripos (Rodríguez et al., 2012; Nagai et al., 2013).

In the present study, the occurrence of PTX in the 50-200 $\mu \mathrm{m}$ size fractions was observed together with the presence of two potentially toxic Dinophysis species, Dinophysis tripos and Dinophysis acuminata. However, cells of $D$. acuminata ranging in size from 39 to $53 \mu \mathrm{m}$ (Balech, 2002) and from $\approx 25$ to $45 \mu \mathrm{m}$ (this

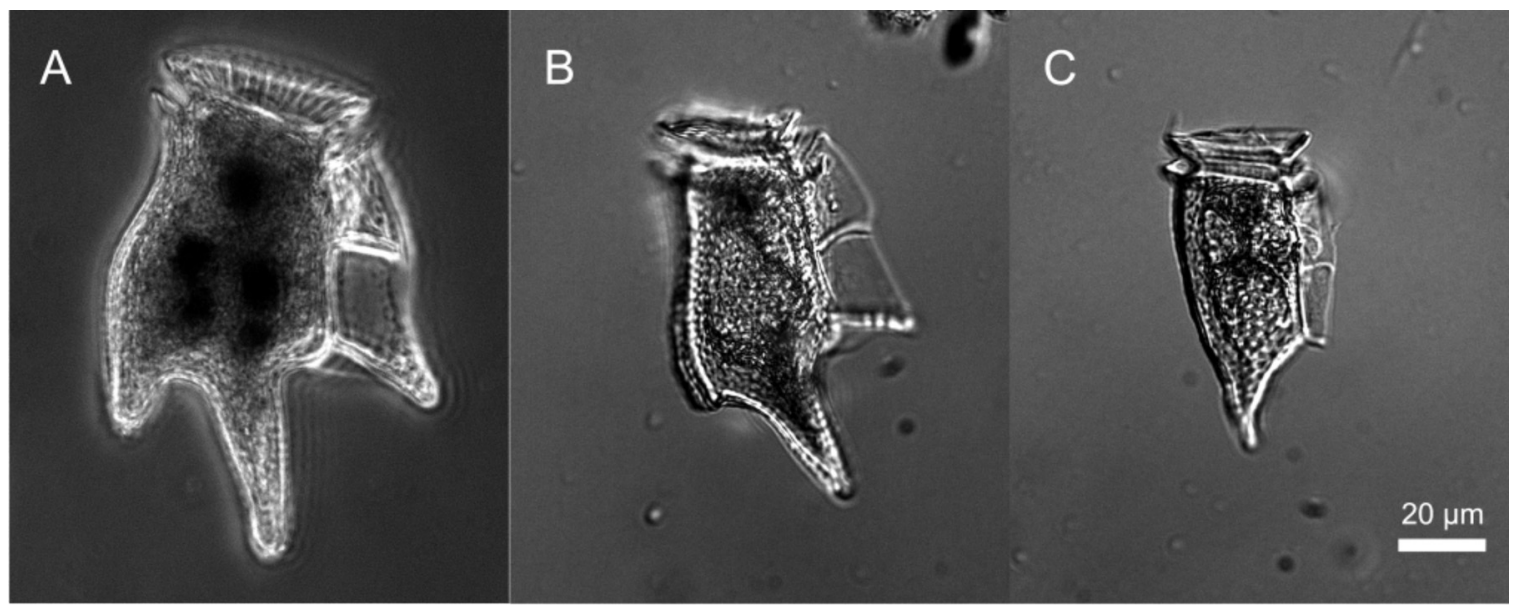

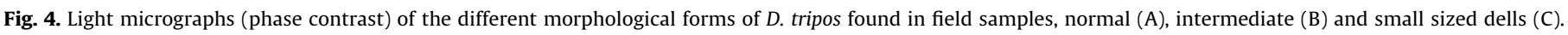




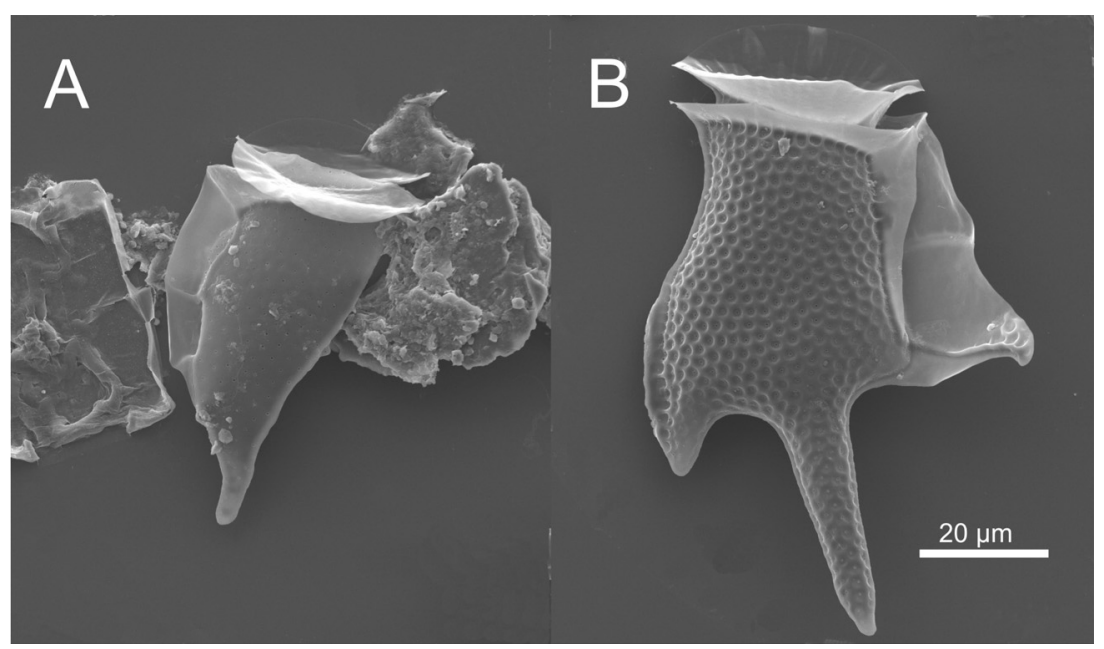

Fig. 5. Electronic micrographs of small (A) and normal (B) cells of Dinophysis tripos, showing the different hypothecal areolation.

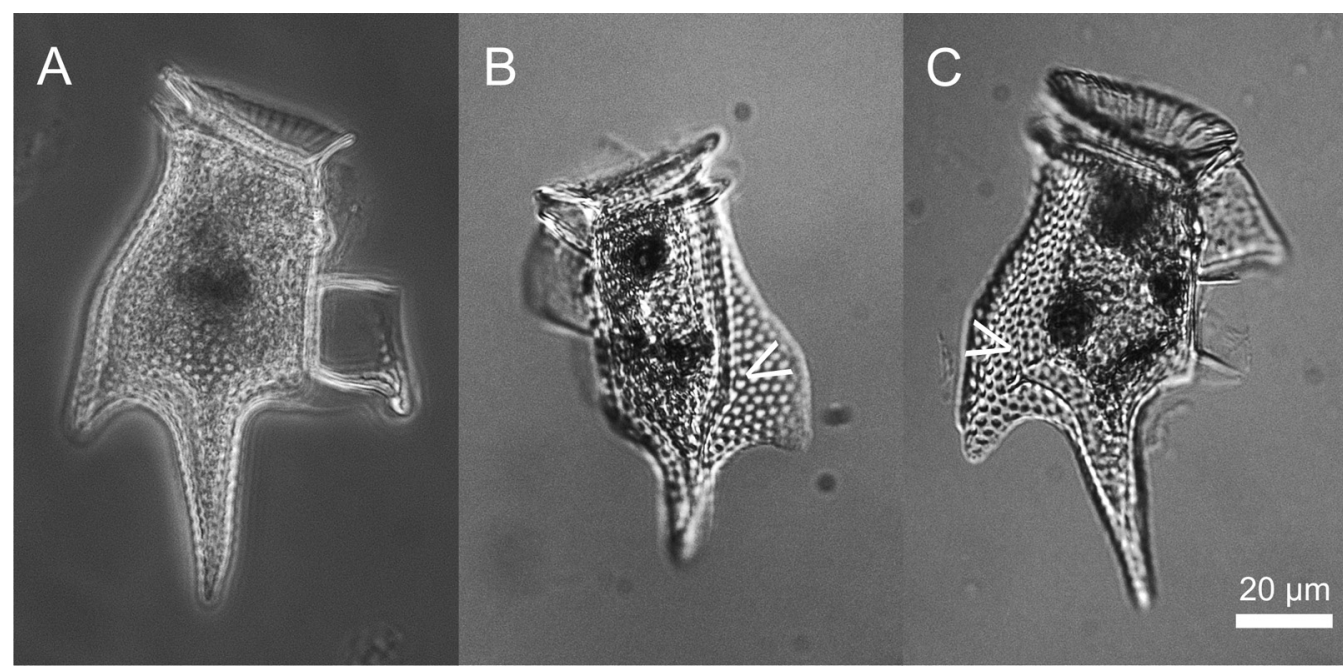

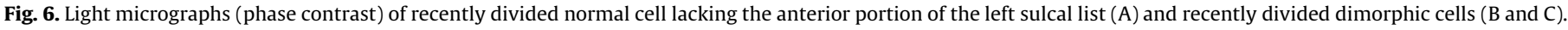
Arrows show the small (B) and intermediate (C) part of the thecae.

study) are expected to be collected in the 20-50 $\mu \mathrm{m}$ size fraction, but most PTX were detected in the 50-200 $\mu \mathrm{m}$ fraction, which argues against a substantial contribution of $D$. acuminata to the PTX detected. In addition, in six samples from the second expedition in which PTX-2sa was detected, $D$. tripos was the only toxic species found in any of these size fractions. In five samples containing PTX2 and in two with presence of PTX-11 D. tripos also was the only toxic species found. In contrast, $D$. acuminata was detected always co-occurring with $D$. tripos in the samples with PTX from expedition 2.

Pectenotoxin-11 has been reported from New Zealand (Suzuki et al., 2003), the Galician Rías, Spain (Pizarro et al., 2008), North Sea (Krock et al., 2008), along the Chilean coast (Blanco et al., 2007; Krock et al., 2009; Trefault et al., 2011) and from the Benguela Current, South Africa (Pitcher et al., 2011), but this is the first report for the Argentinean Sea. Although this toxin was already associated with Dinophysis acuta (MacKenzie et al., 2005; Suzuki et al., 2006) and Dinophysis acuminata (MacKenzie et al., 2005), our data do not strongly support Dinophysis tripos being a producer of PTX-11, because there was little correlation between the toxin and the species $(r=0.67)$. A possible explanation for this low correlation is that $D$. tripos might feed on the original producer of the toxin which could be $D$. acuminata, as it was present in some stations. Although dinoflagellates are known to feed on diverse taxa including other dinoflagellates (Tillman, 2004), this feeding behavior has not been reported for $D$. tripos, but it cannot be entirely excluded, as the genus Dinophysis is known to be mixothrophic and that growth of Dinophysis spp. are based on prey-predator interactions (Park et al., 2006; Nishitani et al., 2008). However, as D. tripos was the only toxic species in two samples from expedition 2 that contend PTX-11, cell quotas in those samples were calculated (0.08 and $0.12 \mathrm{pg} \mathrm{cell}^{-1}$ ).

The finding of PTX-2 production associated to Dinophysis tripos in the Argentine Sea is in accordance with recent experimental and field observations in other regions (Rodríguez et al., 2012; Nagai et al., 2013). The PTX-2 cell quota estimated in our field study (0.03-0.35 $\left.\mathrm{pg} \mathrm{cell}^{-1}\right)$ is considerably lower than those obtained in Japanese cultures $\left(0.8 \pm 29.1 \mathrm{pg} \mathrm{cell}^{-1}\right.$ at the beginning of incubation and $1235.6 \pm 96.1 \mathrm{pg} \mathrm{cell}^{-1}$ at the end of incubation) by Nagai et al. (2013). However, the high PTX cell quota found in Japanese cultures could be a result of measurement of intra and extracellular toxin content. Pectenotoxin-2 cell quotas obtained in field (45$90 \mathrm{pg} \mathrm{cell}^{-1}$ ) and culture (179-232 $\mathrm{pg} \mathrm{cell}^{-1}$ ) samples from the Galician Rías (Rodríguez et al., 2012) are also higher than cell quotas in our study.

Variability in cell toxin content and PTX composition can be high among different Dinophysis spp. populations (Lee et al., 1989), even within the same species and geographical area, as was found 
between the coasts of the western and the eastern North Sea (Krock et al., 2008), and differential production of toxins in the same species can vary considerably even within specimens collected in the same locality (Fernández et al., 2006). Although variation in toxin production is very common, the cell quotas of PTX-2 found in this study are strikingly low. The average PTX-2 cell quota of Dinophysis tripos found during the second expedition was calculated as $0.1 \mathrm{pg} \mathrm{cell}^{-1}$. This is less than $10 \%$ of PTX-2sa, cell quota $1.6 \mathrm{pg}$ cell $^{-1}$, which is dominating the profile. This is quite unusual, because to date PTX-2 always has been found to be the most abundant variant in PTX profiles of the genus Dinophysis (Reguera et al., 2014 and citations therein). However, it seems that, other than in most Dinophysis spp., D. tripos either metabolizes PTX-2 further to PTX-2sa or the biosynthesis of PTX-2 in this species is only a minor biosynthetic pathway and PTX-2sa is biosynthesized independently as the main metabolic product.

Pectenotoxin-2sa is commonly associated to enzymatic hydrolysis of PTX-2 in mussels (Miles et al., 2004b; Wilkins et al., 2006) or to enzymatic conversion after phytoplankton cell rupture (Fernández et al., 2006). In this sense, association between PTX2-sa and Dinophysis caudata has been previously mentioned, but it was interpreted as a result of cell rupture due to sampling methodology or transportation of the samples (Takahashi et al., 2007). However, this can be excluded in our case, because at stations from expedition 1 with dominance of Dinophysis acuminata PTX-2 was the most abundant PTX in the $20-50 \mu \mathrm{m}$ fraction size and only traces of PTX-2sa were detected. Given that samples from both expeditions (and different size fractions) were treated the same way, it is extremely unlikely that hydrolysis of PTX-2 has occurred only in those samples containing Dinophysis tripos, but not in those containing $D$. acuminata. Another possibility to explain PTX-2sa content is that $D$. tripos has been feeding on other Dinophysis species (e.g. D. acuminata) that produce PTX-2 and it has hydrolyzed the toxin through enzymatic digestive reactions (MacKenzie et al., 2012), but this has not been proven at the present. A third possible explanation would be copepod fecal pellets (i.e., assuming copepod grazing on Dinophysis species) (Maneiro et al., 2002) that were frequently observed occurring in the $20-200 \mu \mathrm{m}$ size fractions. However, the lack of quantitative data prevent this can be a proof. Finally, a fourth explanation would be the micrograzer predation on $D$. tripos.

Several potential predators of Dinophysis were observed in the 20-200 $\mu \mathrm{m}$ size fractions of some samples (Table 2). Among the possible predators, we postulate the ciliate Tiarina fusus which has been mentioned as consuming autotrophic dinoflagellates by Hansen (1991). Also, Favella ehrenbergii and Favella serrata, within tintinnids, which have also been signaled as predators on the

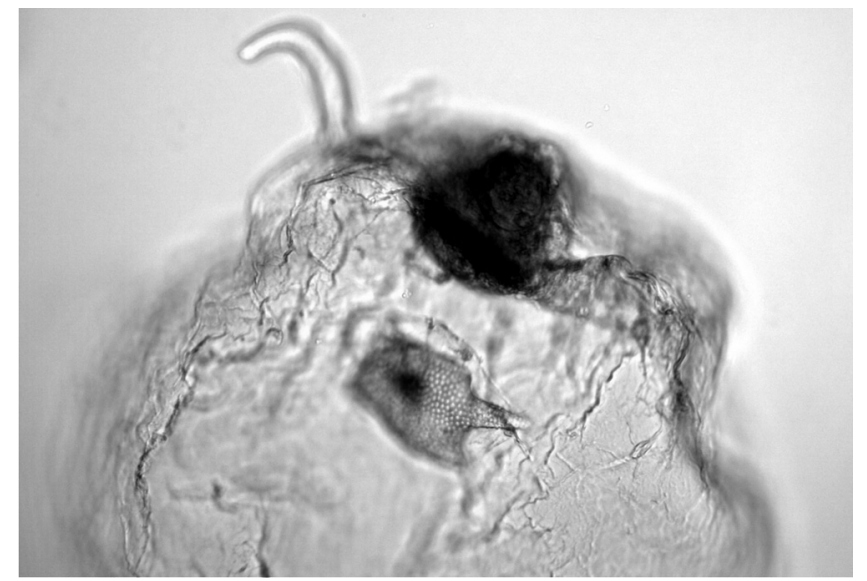

Fig. 7. Image of Noctiluca scintillans (length: $300 \mu \mathrm{m})(20 \times)$ containing a $D$. tripos partially empty thecae. nanoflagellate Azadinium spp. (Krock et al., 2009) and Dinophysis acuminata (Maneiro et al., 2000) respectively. However, the association between these potential predators of Dinophysis tripos and PTX-2sa was not significant $\left(r_{\max }=0.45\right)$. Also in samples $8 \mathrm{~K} 2$ and $9 \mathrm{~K} 2$, with the highest values of PTX-2sa, potential predators were not detected or present at reduced abundances (Table 2).

In summary, considering that the four previous hypotheses are not conclusive to explain the high amount of PTX-2sa in the 50$200 \mu \mathrm{m}$ size fraction, and the high correlation observed between PTX-2sa concentration and Dinophysis tripos abundances, our data suggest this species as a producer of PTX-2sa, showing cell quotas ranging between 0.48 and $6.2 \mathrm{pg}^{-1}$ cell $^{-1}$ in the second expedition, and a higher value (11.6 $\mathrm{pg} \mathrm{cell}^{-1}$ ) at station $\mathrm{I} 50$ from expedition 1. This relation between PTX-2sa and Dinophysis spp. (8.16 pg cell ${ }^{-1}$ ) was previously reported for natural plankton food suspensions rich in Dinophysis norvegica cells (Kozlowsky-Suzuki et al., 2006). However, additional field studies as well as culture establishment are required to unambiguously elucidate the toxin profile of this species and the possible production of PTX-2sa by this genus, as well as to test its bioaccumulation in the food web.

With the purpose to explore a possible transfer of PTX through the food web, the $>200 \mu \mathrm{m}$ size fractions were analyzed for putative Dinophysis tripos predators. Numerous individuals of the large heterotrophic dinoflagellate Noctiluca scintillans, with body diameter range of $200-750 \mu \mathrm{m}$ according to Sato et al. (2004), were observed containing partial or completely empty $D$. tripos thecae (Fig. 7), so predation of $N$. scintillans on this dinoflagellate seems clear. This finding agrees with the report of Sato et al. (2004) which mentions $D$. tripos being part of the diet of $N$. scintillans at a costal fixed station (EPEA, $38^{\circ} 28^{\prime} \mathrm{S}, 57^{\circ} 41^{\prime} \mathrm{W}$ ) from the Argentine Sea shelf. These authors reported that $N$. scintillans is an opportunistic predator grazing on the most abundant microplankton items present in the water column such as copepod eggs, diatoms, tintinnids and $D$. tripos. As such $N$. scintillans has also been recorded to feed on Dinophysis acuta and Dinophysis caudata (Escalera et al., 2007) in the Galician Rías. In addition, this is a cosmopolitan heterotrophic dinoflagellate producer of red tides in numerous coastal areas in the world during spring-summer (Montani et al., 1998; Fonda-Umani et al., 2004). It has been classified as phagotrophic and its feeding mechanism is by engulfing preys (Hansen \& Calado, 1999). The occurrence of $N$. scintillans as well as different copepodites would explain the observed levels of PTX-2sa toxin in the $>200 \mu \mathrm{m}$ fraction size. However, it is not possible to exclude the possibility that some $D$. tripos cells may have been retained on the $200 \mu \mathrm{m}$ mesh and contributed to the PTX-2sa presence in this fraction.

Morphological analyses of Dinophysis tripos revealed different morphotypes in almost all populations of the Argentinean Sea. This was already pointed for other populations, as formation of intermediate and small cell forms and dimorphic cells have been recorded for a number of species of the genus Dinophysis (Reguera \& González-Gil, 2001). Presence of recently divided cells lacking part of the left sulcal list was also detected in our field samples, which is a sign of recent cellular division. In our material all these forms were commonly observed as part of $D$. tripos populations, and their characteristics were in accordance with those previously described from culture and field samples by Rodríguez et al. (2012). However, intermediate and small cells represented only a small percentage of total abundance (0.18-2.54) when compared with other values observed in Dinophysis spp. (10-45\%) by Reguera \& González-Gil (2001).

\section{Conclusion}

This is the first record of association between Dinophysis tripos and toxins in Argentine Sea, where DSP events and detection of 
DTX-1 and OA have been previously linked to Dinophysis acuminata and Dinophysis caudata (Sar et al., 2012). Pectenotoxin-11 and PTX2sa are found for the first time in this area. The recurrent finding of different PTX but lack of OA or its analogs agrees with results from the Baltic Sea (Setälä et al., 2011) and from the Chilean coast (Blanco et al., 2007; Krock et al., 2008).

\section{Funding}

This work was partially financed by the Helmholtz-Gemeinschaft Deutscher Forschungszentren through the research programme PACES of the Alfred Wegener Institut-Helmholtz Zentrum für Polar- und Meeresforschung and the binational project MINCyT-BMBF (AL/11/03-ARG 11/021), and supported by PIP 00173 (CONICET) grant and by the European Commission under the 7th Framework Programme through the Action-IMCONet (FP7 IRSES, Action No. 319718).

\section{Acknowledgements}

The authors thank Sebastian Göller for plankton sampling and processing during expedition 2 and Wolfgang Drebing for sample extraction and toxin measurements. In addition, the friendly reception and support of the $2012 \mathrm{crew}$ of the $R / V$ Puerto Deseado (CONICET-MINDEF, Argentina) and the $2013 \mathrm{crew}$ of the $R / V$ "Bernardo Houssay" (Prefectura Naval Argentina) are acknowledged.[SS]

\section{References}

Agatha, S., Riedel-Lorje, J.C., 1997. Morphology, infraciliature and ecology of halteriids and strombidiids (Ciliophora, Oligotrichea) from coastal brackish water basins. Archiv für Protistenkunde 148 (4) 445-459.

Alder, V., 1999. Tintinnoinea. In: Boltovskoy, D. (Ed.), South Atlantic Zooplankton. Backhuys Publishers, Leiden, pp. 321-384.

Balech, E., 1988. Los dinoflagelados del Atlántico Sudoccidental. Publicaciones Especiales, Instituto Español de Oceanografía, , pp. 310.

Balech, E., 2002. Dinoflagelados tecados tóxicos del Cono Sur Americano. In: Sar, E.A., Ferrario, M.E., Reguera, B. (Eds.), Floraciones algales nocivas en el Cono Sur Americano. Instituto Español de Oceanografía, Madrid, pp. 123-144.

Blanco, J., Alvarez, G., Uribe, E., 2007. Identification of pectenotoxins in plankton, filter feeders, and isolated cells of a Dinophysis acuminata with an atypical toxin profile, from Chile. Toxicon 49 (5) 710-716.

Boltovskoy, D., 1981. Atlas del zooplancton del Atlántico Sudoccidental y métodos de trabajo con el zooplancton marino. Instituto Nacional de Investigación y Desarrollo Pesquero. Publicación Especial, Mar del Plata, pp. 937.

Domínguez, H.J., Paz, B., Daranas, A.H., Norte, M., Franco, J.M., Fernández, J.J., 2010. Dinoflagellate polyether within the yessotoxin, pectenotoxin and okadaic acid toxin groups: characterization, analysis and human health implications. Toxicon 56, 191-217.

Draisci, R., Lucentini, L., Giannetti, L., Boria, P., Poletti, R., 1996. First report of pectenotoxin-2 (PTX-2) in algae (Dinophysis fortii) related to seafood poisoning in Europe. Toxicon 34, 923-935.

Escalera, L., Pazos, Y., Moron, A., Reguera, B., 2007. Noctiluca scintillans may act as a vector of toxigenic microalgae. Harmful Algae 6, 317-320.

Fernández, M.L., Reguera, B., González-Gil, S., Míguez, A., 2006. Pectenotoxin-2 in single-cell isolates of Dinophysis caudata and Dinophysis acuta from the Galician Rías (NW Spain). Toxicon 48, 477-490.

Fonda-Umani, S., Beran, A., Parlato, J., Virgilio, D., Zollet, T., de Olazabal, A., Lazzarini, B., Cabrini, M., 2004. Noctiluca scintillans (Macartney) in the northern Adriatic Sea: long-term dynamics, relationships with temperature and eutrophication, and role in the food web. J. Plankton Res. 26, 545-561.

Gómez, F., López-García, P., Moreira, D., 2011. Molecular phylogeny of dinophysoid dinoflagellates: the systematic position of Oxyphysis oxytoxoides and the Dinophysis hastata group (Dinophysales, Dinophyceae). J. Phycol. 47, 393-406.

Hansen, P.J., 1991. Dinophysis - a planktonic dinoflagellate genus which can act both as a prey and a predator of a ciliate. Mar. Ecol. Prog. Ser. 69, 201-204.

Hansen, P.J., Calado, A.J., 1999. Phagotrophic mechanisms and prey selection in freeliving dinoflagellates. J. Eukaryot. Microbiol. 46, 382-389.

Hastrup-Jensen, M., Daugbjerg, N., 2009. Molecular phylogeny of selected species of the order Dinophysiales (Dinophyceae) - testing the hypothesis of a dinophysioid radiation. J. Phycol. 45, 1136-1152.

Johnsen, T.M., Lømsland, E.R., 2010. Observations of Dinophysis tripos in Norwegian coastal waters. In: Pagou, P., Hallegraeff, G.M. (Eds.), Proceedings of the 14th International Conference on Harmful Algae, Creta, Greece, 1-2 November 2010.
International Society for the Study of Harmful Algae and Intergovernmental Oceanographic Commission of UNESCO, Copenhagen, Denmark, pp. 54-56.

Kogan, M., 2005. Estudio de la composición específica, abundancia y distribución espacial del microzooplancton (protozoos y micrometazoos) en el estuario del Río de la Plata (Argentina-Uruguay). Tesis doctoralUniversidad de Buenos Aires, Buenos Aires, pp. 157.

Kozlowsky-Suzuki, B., Carlsson, P., Rühl, A., Granéli, E., 2006. Food selectivity and grazing impact on toxic Dinophysis spp. by copepods feeding on natural plankton assemblages. Harmful Algae 5, 57-68.

Krock, B., Tillmann, U., Selwood, A.I., Cembella, A., 2008. Unambiguous identification of pectenotoxin-1 and distribution of pectenotoxins in plankton from the North Sea. Toxicon 52, 927-935.

Krock, B., Seguel, C.G., Valderrama, K., Tillmann, U., 2009. Pectenotoxins and yessotoxin from Arica Bay, North Chile as determined by tandem mass spectrometry. Toxicon 54 (3) 364-367.

Larsen, J., Moestrup, Ø., 1992. Potentially toxic phytoplankton 2. Genus Dinophysis (Dinophyceae). In: Lindley, J.A. (Ed.), ICES Identification Leaflets for Plankton. ICES, Copenhagen, pp. 1-12.

Lee, J.S., Igarashi, T., Fraga, S., Dahl, E., Hovgaard, P., Yasumoto, T., 1989. Determination of diarrhetic shellfish toxins in various dinoflagellate species. J. Appl. Phycol. 1, 147-152.

LeGresley, M., McDermott, G., 2010. Counting chamber methods for quantitative phytoplankton analysis - haemocytometer, Palmer-Maloney cell and Sedgewick-Rafter cell. In: Karlson, B., Cusac, C., Bresnan, E. (Eds.), Microscopic and Molecular Methods for Quantitative Phytoplankton Analysis. UNESCO, p. 25.

MacKenzie, L., Beuzenberg, V., Holland, P., McNabb, P., Suzuki, T., Selwood, A., 2005. Pectenotoxin and okadaic acid-based toxin profiles in Dinophysis acuta and Dinophysis acuminata from New Zealand. Harmful Algae 4, 75-85.

MacKenzie, L.A., Selwood, A.I., Marshall, C., 2012. Isolation and characterization of an enzyme from the Greenshell mussel Perna canaliculus that hydrolyses pectenotoxins and esters of okadaic acid. Toxicon 60, 406-419.

Maneiro, I., Frangopolus, M., Guisande, C., Fernández, M., Reguera, B., Barreiro, I., 2000. Zooplankton as a potential vector of diarrheic shellfish poisoning toxins through the food web. Mar. Ecol. Prog. Ser. 201, 155-163.

Maneiro, I., Guisande, C., Frangópulos, M., Riveiro, I., 2002. Importance of copepod faecal pellets to the fate of the DSP toxins produced by Dinophysis spp. Harmful Algae 1 (4) 333-341.

Miles, C.O., Wilkins, A.L., Munday, R., Dines, M.H., Hawkes, A.D., Briggs, L.R., Sandvik, M., Jensen, D.J., Cooney, J.M., Holland, P.T., Quilliam, M.A., MacKenzie, A.L., Beuzenberg, V., Towers, N.R., 2004a. Isolation of pectenotoxin-2 from Dinophysis acuta and its conversion to pectenotoxin-2 seco acid and preliminary assessment of their acute toxicities. Toxicon 43, 1-9.

Miles, C.O., Wilkins, A.L., Samdal, I.A., Sandvik, M., Petersen, D., Quilliam, M.A., Naustvoll, L.J., Jensen, D.J., Cooney, J.M., 2004b. A novel pectenotoxin, PTX-12, in Dinophysis spp. and shellfish from Norway. Chem. Res. Toxicol. 17, 14231433.

Montani, S., Pithakpol, S., Tada, K., 1998. Nutrient regeneration in coastal seas by Noctiluca scintillans, a red tide-causing dinoflagellate. J. Mar. Biotechnol. 6 , 224-228.

Montagnes, D.J.S., Lynn, D.H., 1991. Taxonomy of choreotrichs, the major marine planktonic ciliates, with emphasis on the aloricate forms. Mar. Microb. Food Webs 5, 59-74.

Montagnes, J.S.D., Taylor, F.J., 1994. The salient features of five marine ciliates in the Class Spirotrichea (Oligotrichia) with notes on their culturing and behaviour. J. Eukaryot. Microbiol. 4 (6) 586-596.

Montagnes, D.J.S., Lynn, D.H., Stoecker, D.K., Small, E.B., 1988. Taxonomic descriptions of one new species and redescription of four species in the family Strombidiidae (Ciliophora, Oligotrichida). J. Protozool. 35 (2) 189-197.

Montoya, N.G., Carignan, M.O., Benavidez, H.O., 2013. Toxinas emergentes en el Mar Argentino. In: Reunião Latino-americana sobre Algas Nocivas, Florianópolis, Brasil, p. 12

Nagai, S., Suzuki, T., Kamiyama, T., 2013. Successful cultivation of the toxic dinoflagellate Dinophysis tripos (Dinophyceae). Plankton Benthos Res. 8, 171-177.

Nishitani, G., Nagai, S., Sakiyama, S., Kamiyama, T., 2008. Successful cultivation of the toxic dinoflagellate Dinophysis caudata (Dinophyceae). Plankton Benthos Res. 3 (2) 78-85.

Park, M.G., Kim, S., Kim, H.S., Myung, G., Kang, Y.G., Yih, W., 2006. First successful culture of the marine dinoflagellate Dinophysis acuminata. Aquat. Microb. Ecol. 45, 101-106.

Petz, W., 1999. Ciliophora. In: Boltovskoy, D. (Ed.), South Atlantic Zooplankton. Backhuys Publishers, Leiden, pp. 265-319

Pitcher, G.C., Krock, B., Cembella, A.D., 2011. Accumulation of diarrhetic shellfish poisoning toxins in the oyster Crassostrea gigas and the mussel Choromytilus meridionalis in the southern Benguela ecosystem. Afr. J. Mar. Sci. 33 (2) 273-281.

Pizarro, G., Paz, B., Franco, J.M., Suzuki, T., Reguera, B., 2008. First detection of pectenotoxin-11 and confirmation of OA-D8 diol-ester in Dinophysis acuta from European waters by LC-MS/MS. Toxicon 52 (8) 889-896.

Quilliam, M.A., 2003. Chemical method for lipophilic shellfish toxins. In: Hallegraeff G.M., Anderson, D.M., Cembella, A.D. (Eds.), Manual on Harmful Marine Microalgae. UNESCO Publishing, Paris, France, pp. 211-245.

Reguera, B., González-Gil, S., 2001. Small cell and intermediate cell formation in species of Dinophysis (Dinophyceae, Dinophysiales). J. Phycol. 37, 318-333.

Reguera, B., Riobó, P., Rodríguez, F., Díaz, P.A., Pizarro, G., Paz, B., Franco, J.M., Blanco, J., 2014. Dinophysis toxins: causative organisms, distribution and fate in shellfish. Mar. Drugs 12, 394-461. 
Rodríguez, F., Escalera, L., Reguera, B., Rial, P., Riobó, P., Silva, T.J., 2012. Morphological variability, toxicology and genetics of the dinoflagellate Dinophysis tripos (Dinophysiaceae, Dinophysiales). Harmful Algae 13, 26-33.

Sar, E.A., Sunsen, I., Lavigne, A.S., Goya, A.B., 2010. Dinophysis spp. asociadas a detección de toxinas diarreicas en moluscos (DSTs) y a intoxicación diarreica en humanos (Provincia de Buenos Aires, Argentina). Rev. Biol. Mar. Oceanogr. 45 451-460.

Sar, E.A., Sunsen, I., Goya, A.B., Lavigne, A.S., Tapias, E., García, C., Lagos, N., 2012. First report of diarrheic shellfish toxins in mollusks from Buenos Aires Province (Argentina) associated with Dinophysis spp.: evidence of okadaic acid, dinophysis toxin-1 and their acyl derivatives. Bol. Soc. Argent. Bot. 47 (1-2) 5-14.

Sato, N.E., Hernández, D., Viñas, M.D., 2004. Hábitos alimentarios de Noctiluca scintillans en aguas costeras de la Provincia de Buenos Aires, Argentina. Lat. Am. J. Aquat. Res. 38 (2) 403-412.

Setälä, O., Sopanen, S., Autio, R., Erler, K., 2009. Grazing and prey selectivity of the calanoid copepods Eurytemora affinis and Acartia bifilosa feeding on plankton assemblages containing Dinophysis spp. Boreal Environ. Res. 14, 837-849.

Setälä, O., Sopanen, S., Autio, R., Kankaanpää, H., Erler, K., 2011. Dinoflagellate toxins in northern Baltic Sea phytoplankton and zooplankton assemblages. Boreal Environ. Res. 16, 509-520.

Suzuki, T., Mitsuya, T., Matsubara, H., Yamasaki, M., 1998. Determination of pectenotoxin-2 after solid-phase extraction from seawater and from the dinoflagellate Dinophysis fortii by liquid chromatography with electrospray mass spectrometry and ultraviolet detection. Evidence of oxidation of pectenotoxin-2 to pectenotoxin-6 in scallops. J. Chromatogr. A 815, 155-160.

Suzuki, T., Beuzenberg, V., Mackenzie, L., Quilliam, M.A., 2003. Liquid chromatography-mass spectrometry of spiroketal stereoisomers of pectenotoxins and the analysis of novel pectenotoxin isomers in the toxic dinoflagellate Dinophysis acuta from New Zealand. J. Chromatogr. A 992 (1-2) 141-150.

Suzuki, T. Walter, J.A, Leblanc, P., Mackinnon, S., Miles, C.O., Wilkins, A.L., Munday, R., Beuzenberg, V., Mackenzie, A.L., Jensen, D.J., Cooney, J.M., Quilliam, M.A., 2006. Identification of pectenotoxin-11 as 34s-hydroxypectenotoxin-2, a new pectenotoxin analogue in the toxic dinoflagellate Dinophysis acuta from New Zealand. Chem. Res. Toxicol. 19, 310-318.

Suzuki, T., Miyazono, A., Baba, K., Sugawara, R., Kamiyama, T., 2009. LC-MS/MS analysis of okadaic acid analogues and other lipophilic toxins in single-cel isolates of several Dinophysis species collected in Hokkaido. Jpn. Harmful Algae 8, 233-238.

Takahashi, E., Yu, Q., Eaglesham, G., Connel, D.W., McBroom, J., Costanzo, S., Shaw, G.R., 2007. Occurrence and seasonal variations of algal toxins in water, phytoplankton and shellfish from North Stradbroke Island, Queensland, Australia. Mar. Environ. 64, 429-442.

Teegarden, G.J., Cembella, A.D., 1996. Grazing of toxic dinoflagellates, Alexandrium spp., by adult copepods of coastal Maine: implications for the fate of paralytic shellfish toxins in marine food webs. J. Exp. Mar. Biol. Ecol. 196, $145-176$.

Terao, K., Ito, E., Yanagi, T., Yasumoto, T., 1986. Histopathological studies on experimental marine toxin poisoning. I. Ultrastructural changes in the small intestine and liver of suckling mice induced by dinophysistoxin- 1 and pectenotoxin-1. Toxicon 24, 1141-1151.

Tester, P.A., Turner, J.T., Shea, D., 2000. Vectorial transport of toxins from the dinoflagellate Gymnodinium breve through copepods to fish. J. Plankton Res. 22, 47-62.

Tillman, U., 2004. Interactions between planktonic microalgae and protozoan grazers. J. Eukaryot. Microbiol. 51, 156-168.

Trefault, N., Krock, B., Delherbe, N., Cembella, A., Vásquez, M., 2011. Latitudinal transects in the southeastern Pacific Ocean reveal a diverse but patchy distribution of phycotoxins. Toxicon 58, 389-397.

Utermöhl, H., 1931. Neue Wegeinderquantitative Erfassungdes Planktons (mit besonderer BerucksichtigungdesUltraplanktons). Verh. Int. Ver. Theor. Angew. Limnol. 5, 567-596.

Wilkins, A.L., Rehmann, N., Torgersen, T., Rundberget, T., Keogh, M., Petersen, D. Hess, P., Rise, F., Miles, C.O., 2006. Identification of fatty acid esters of pectenotoxin-2 seco acid in blue mussels (Mytilus edulis) from Ireland. J. Agric. Food Chem. 54, 5672-5678.

Yasumoto, T., Sugawara, W., Fukuyo, Y., Oguri, H., Igarashi, T., Fujita, N., 1980. Identification of Dinophysis fortii as the causative organism of diarrhetic shellfish poisoning in the Tohoku district. Bull. Jpn. Soc. Sci. Fish. 46, 1405-1411.

Zingone, A., Larsen, J., 2014. DinophysialesIn: IOC-UNESCO Taxonomic Reference List of Harmful Micro Algae. . Available at: http://www.marinespecies.org/HAB (accessed 20.03.14.) 